脳に損傷を負って意識が戻らないまま身体は生き続けている状 態を、一般に「植物状態 (vegetative state)」とよんでいます。 しかし最近、「植物状態」と診断されていても外部からの刺激 に対して脳内活動を示す患者がいることが、脳スキャンを使っ た研究で示されたため、その定義や基準が摇らいでいます。
Nature では、この話題を 2006 年 9 月 14 日号の論説記事 およびNewsで取り上げました。以下の論説記事を読んで、 研究の内容をより詳しく知りたい場合には、News（Michael Hopkin, Nature 443,132-133）にも挑戦してみましょう。

\title{
Editorial
}

語数 : 528 words 分野 : 神経·医療倫理

Nature 443, 121-122 | doi: 10.1038/443121b; Published online 13 September 2006

\section{Flickers of consciousness}

http://www. nature.com/nature/journal/v443/n7108/full/443121b.html

Brain scans are forcing researchers to reconsider the state of outwardly unresponsive patients.

1. The news that a patient in a vegetative state has shown signs of awareness of the outside world, and an ability to perform mental tasks on request, marks a turning point in the investigation of these enigmatic medical conditions. It also means that neuroscientists have some serious thinking to do.

2. The evaluation of vegetative states, in which patients are often 'awake' but show no outward sign that they are aware of themselves or their environment, has always been difficult, simply because of the huge variability in the nature and severity of the brain injuries that underpin them. What is often so heartbreaking for friends and relatives is that the patient's mental quality of life is unknowable.

3. In the wake of the latest research (A. M. Owen et al. Science 313, 1402; 2006), the inevitable calls for all 'vegetative' patients to be considered internally conscious should not be heeded. This case has little bearing on ethical questions over whether or not the most severe cases should be denied treatment and allowed to die. Clearly, for those with the bleakest prognosis - those who have shown no improvement over a period of at least 12 months and are categorized as being in a 'permanent vegetative state' - the chances of finding any sign of awareness are negligible.

4. But when considering those at the less severe end of the spectrum, such as the British patient at the heart of the latest research, the new discovery presents a conundrum. Loved ones of similar patients will clamour for a chance to see whether they, too, are capable of similar feats. Clinical neuroscientists should stress that no two vegetative patients are alike, and that this remarkable case may be a one-off.

5. Unique or not, the discovery blurs the distinction between a vegetative patient and those classed as 'minimally conscious' - showing limited or intermittent interaction with their surroundings. As the patient has reportedly improved since the study was carried out, it is entirely possible that the brain scans simply reflected early signs of her recovery. But with brain scanning of vegetative patients becoming more common (although far from routine), the medical criteria for diagnosing a vegetative condition will have to be scrutinized.

6. A patient is currently classed as vegetative if there are no outward signs of genuine awareness, rather than simple reflex responses to stimuli such as pain. But although this patient remained inscrutable throughout the study, her brain scans suggested she was picturing herself scampering across a tennis court, or roaming around her home. If such rich internal mental processes are seen in other outwardly vegetative patients, then clinicians should revise their opinion on whether or not these patients are really vegetative at all. 
7. Some clinicians take issue with the use of the word 'vegetative' and the unpleasant imagery it evokes. Replacing it with the term 'outwardly unresponsive' would help to eliminate any confusion over whether internal awareness should be factored into a diagnosis. But the ultimate impact of this discovery will hinge on whether more patients are found to have this sort of inner responsiveness. Then, the issue of what constitutes consciousness in these patients a question that transcends mere brain imaging - will come alive.

\section{定義}

植物状態とは、自分自身および自分の環境をまったく認識していな いが、睡眠覚醒サイクルは存在しており、視床下部および脳幹の自 律機能が全面的または部分的に維持されている臨床状態を指す。

\section{診断基準}

植物状態の診断は、以下の基準を使って行うことができる。 植物状態にある患者には、以下の徵候がみられる。

自分自身または環境を認識していることを示す証拠がなく、他者 との相互作用ができないこと

視覚刺激、聴覚刺激、触覚刺激または侵害刺激に対する持続性、 再現性、目的性または随意性のある行動反応の存在を示す証拠 がないこと

言語理解または言語表現ができることを示す証拠がないこと 一断続的な覚醒がみられ、睡眠覚醒サイクルの存在が認められること 視床下部および脳幹の自律機能が十分に維持されており、医療 と看護による生存が可能なこと

腸失禁と膀胱失禁があること

保持されている脳神経（瞳孔、眼球回頭、角膜、前庭眼球、咽 頭）反射と脊髄反射の程度にばらつきがみられること

(American Academy of Neurology)

\section{Science key words}

リードｂrain scans: 「脳スキャン」

CTやMRIに代表される脳撮像 (brain imaging) 技術 を意味する。この記事で紹介されている研究では、fMR (functional magnetic resonance imaging、機能的磁気共 鳴画像法）を用いて、所定のタスク（作業、課題）を課した 被験者の脳を走査して、脳の活動状態を撮像している。

1. mental tasks : ここでは、「テニスをしているところを 想像してください」といった精神的なタスクのこと。

6. reflex responses : 「反射応答」

意識の存在が確認できる動物において、特定の刺激に対 して規則的かつ無意識に起こる反応のこと。

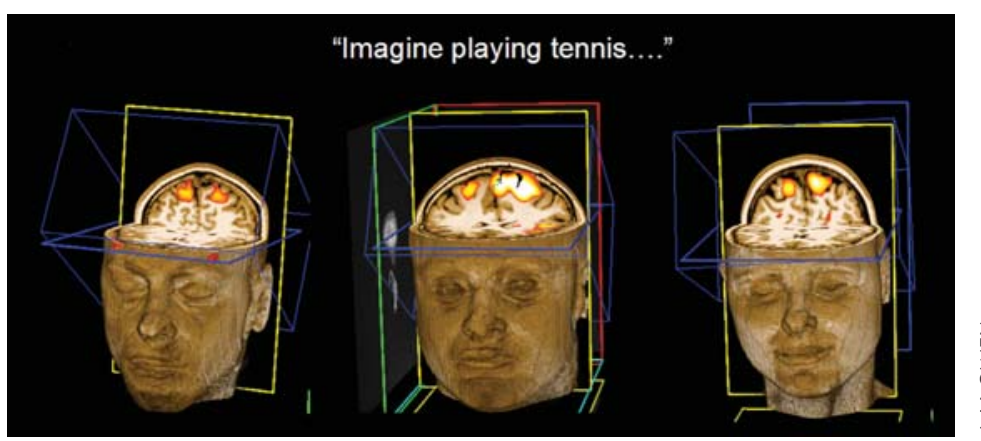

交通事故で植物状態になり 5 か月が経過した 23 歳の女性と、対照となる 12 人の健康な被験 者に「テニスをしているところを想像してください」とそれぞれ指示したところ、どの人で も大脳前頭葉にある補足運動野（SMA）が同じように活性化した。

\section{Words and phrases}

タイトル flickers of ... : 「かすかな〜」「わずかな〜」 flicker は「ちらつき」「(炎の) ゆらめき」といった意味。

リード outwardly unresponsive : 外面的に（outwardly）無反応な状態 (unresponsive)、つまり「体を動かす」「言葉を発する」といった反応 がない状態を意味する。「植物状態」という用語が一部で嫌悪されている こともあり、植物状態より具体的な表現で、今回の研究で示された「精神 的には応答している」ケースが含まれるようになっている。

1. marks a turning point : 「転機を迎える」 turning point「転換点、転機」に mark「印をつける」という意味。

1. enigmatic : 「謎めいた、不思議な」「得体の知れない」

名詞の enigma は、わざとわかりにくい比喻を使って読み手や聞き手の知力 を試した散文や韻文のことで、そこから転じて「謎」という意味が引き出された。

2. underpin :「根拠となる、実証する」 もともとは「建造物などを下から支えて補強する」という意味。

3. in the wake of ... : 「〜を受けて」「〜をきっかけに」 wake とは「(船が残した) 波の跡」のことで、そこから in the wake of ... は 「〜のすぐ後に続いて」「〜にならって」という意味となった。

3. be heeded : 「注意を払う」「聞き入れる」

3. has little bearing on ...: $\ulcorner$ とはほとんど関係がない」

3. bleakest prognosis: 「最も見込みのない予後」 prognosis とは「予後」、すなわち病気の経過や結果についての見通し のこと。この語にかかる形容詞（good, badなど）によってその程度を 表すが、ここでは bleak「暗い、希望のない」の最上級を用いて、希望 のもてない状態を強調している。

4. conundrum : 「難解な問題」

もともとは、「語呂合わせの入ったなぞなぞ」という意味。

4. clamour for ... : 「〜 を強く要求する」

clamour は「叫んだり、わめいたりすること」。特に強い主張や不満、 反対の意思を示すための叫びを意味することが多くなった。

4. one-off : $\ulcorner 1$ 回限りの事物」

5. be scrutinized : 「注意深く調べられる」「じろじろと観察される」

6. inscrutable:「調べても解明できない」

6. scampering: 「機敏に動き回ること」

7. take issue with ... : 「〜と反対の立場に立つこと」「〜に反論すること」

7. hinge on ... : 「 に にかっている」「〜に左右される」

名詞 hinge は「(ドアなどの) ちょうつがい」「関節」の意味。広義に は物事の要となる点のことを意味し、その具合によって物事の良し悪し が決まることが連想される。depend on ... とほぼ同じ意味で使われる。 
Nature 443, 121-122 | doi: 10.1038/443121b; Published online 13 September 2006

\section{摇らめく意識}

http://www. nature.com/nature/journal/v443/n7108/full/443121b.html

脳スキャンによって、研究者は、外面的に無反応な患者の状態を再考することを迫られている。

1．ある植物状態の患者が外界を認識していることを示す徵 候がみられ、その患者は、求めに応じて精神的作業を行 う能力を有している、とする研究報告があり、この謎め いた病状の研究が転機を迎えている。またこの研究は、 神経科学者が、この論点をある程度真剣に考える必要が あることも意味している。

2. 植物状態の患者は「覚醒」していることが多いが、自ら あるいは自らの環境を認識していることを示す外面的徵 候はみられない。植物状態の根本原因である脳損傷の性 質と程度が極めて多様だという単純な理由のため、この 状態を評価することには、絶えず困難が付きまとってい た。患者の精神生活の質を知りえないために、患者の親 戚や友人が心を痛めることも多い。

3. 最新の研究報告 (A. M. Owen et al. Science 313, 1402; 2006）を受けて、すべての「植物状態の」患者は内面的 には認識能力があると考えるべきだと主張されることは 避けられないが、それに耳を傾けるべきではないだろう。 この研究で取り上げられた症例は、最も重症の症例にお いて治療を拒否して患者を死なせるべきかどうかという 倫理的問題とは、ほとんど関係がない。予後に最も見込 みのない症例、すなわち 12 か月以上にわたって症状の 改善がみられず、「永久的植物状態」と分類された症例に ついては、認識の徴候が見つかる確率はごくわずかなこ とは明白なのである。

4.しかし、今回の研究の焦点となった英国の患者のように 比較的軽度な症例を考えると、この研究での新発見は 1 つの難問を提起したといえる。これと同じような症状の 患者の家族が、それぞれの患者に際立った能力があるか どうかを調べる機会を与えてほしいと強く求めてくるこ とが予想されるのである。臨床神経科学者は、植物状態 の患者に 2 人として同じ症状の患者はおらず、今回の研 究で示された特筆すべき症例は、この患者にしか当ては まらないかもしれないことを強調すべきだろう。
5. この患者だけなのかどうかはさておき、今回の発見は、 植物状態の患者と「最小意識状態」と分類される患者（周 囲との相互作用が限定的あるいは断続的な患者）の区別 を不明瞭なものにしている。今回の研究では、患者の症 状が検査実施後に改善したことが報告されていることか ら、脳スキャンの結果は単に病状回復の初期徵候だった と考える余地も十分にある。しかし植物状態の患者に対 する脳スキャンが（日常的というにはほど遠いが）従来 よりも頻繁に行われるようになっているため、植物状態 の医学的診断基準を詳細に検討する必要があるだろう。

6. 現在の分類によれば、痛みなどの刺激に対する単純な反 射応答ではなく、本当の認識があることを示す外面的徵 候がない患者は植物状態とされる。今回の研究が行われ ている間、患者の病状は解明されなかったが、患者の脳 スキャンの結果からは、テニスコート上を俊敏に走り回 り、あるいは家の周りを動き回る姿を思い描いているよ うすが示唆された。もしこのように豊かな心的過程がほ かの外面的植物状態の患者にもみられるのであれば、臨 床医はこれらの患者が本当に植物状態にあるのかどうか についての見解を変えるべきだろう。

7.一部の臨床医は、「植物状態」という用語の使用とそれに よって連想される好ましくないイメージに異を唱えてい る。「植物状態」の代わりに「外面的無反応」という用 語を使うことは、内面的認識を診断の際に考慮すべきか どうかをめぐる混乱をなくすうえで役立つかもしれない。 しかし、今回の新知見が究極的に影響力をもてるかどう かは、この種の内面的反応を示す患者が今後も見つかる かどうかにかかっている。もしそうなれば、植物状態の 患者の意識は何によって構成されているのかという論点 が、単なる脳撮像の問題を超越して活発に議論されるよ うになるだろう。 